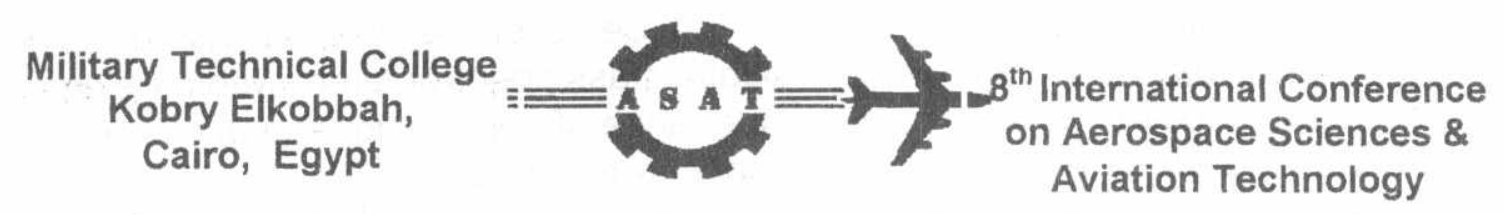

\title{
MASS SPECTROMETRIC STUDY AS A BASE FOR ENVIRONMENTAL MONITORING OF BIS-2-CHLOROETHYL SULPHIDE
}

\author{
M.Sh. Fayed", M.Kassem*, and A.K.Rady*
}

\begin{abstract}
Environmental chemical detection systems have been subjected to extensive development to give sensitive, specific and in time detection of the potentially hazardous chemical compounds mostly is a highly toxic liquid of vesicant action in addition to other severe physiological symptoms. This paper attempts to outline its detection via gas chromatograph-mass spectrometer combined technique. The fragmentation pattern of the mentioned contaminants in the mass spectrometer by electronic impact is proposed and discussed. The relative abundance of unique ions expected to be formed from the chemical pollutant of interest are given and explained. These ions can be used to program a mobile mass spectrometer for the analysis of the contaminant. The technique is characterized by high sensitivity and can be adapted to monitor the contamination in both vapor and liquid forms.
\end{abstract}

\section{KEY WORDS}

Mass spectrometery, Bis (2-chloroethyl) sulphide, Environmental pollution

\section{INTRODUCTION}

It is well known that chemical agents can be easily manufactured through the lines producing agricultural insecticides. As a result of this fact advanced in chemical defense fields are expected via the application of all advanced technologies and techniques. The chemical detection and warning occupy a top position among other chemical defense activities. The chemical detection system must always be ready, efficient, and can be modified or developed to match the new advances in the field. The main requirements in the chemical detectors are sensitivity, specificity and the quick detection and identification of the toxic chemicals in the field. There are

*...Egyptian Military Forces. 
several basic principles used in the detection techniques as: electrochemical, iorization, laser and others [1,2]. Mobile mass spectrometers with an electron impact source is based on the relative abundance of some unique ions associated with the chemical pollutants of interest. The spectrometer can be

programmed for pre-selected set of ions of the pollutants and can be updated for other chemical, [3]. The future chemical detection systems will be more sophisticated portable on vehicles or aircraft's with long range detection capability with the possibility of atmospheric sampling.

\section{EXPERIMENTAL \\ Material}

2,2-thiodiethanol, and $\mathrm{S}\left(\mathrm{CH}_{2} \mathrm{CH}_{2} \mathrm{OH}\right)$, were obtained from Aldrich. Whereas hydrochloric acid, having strength of $33 \%$, was purchased from El-Nasr Chem. Company.

\section{Apparatus}

The mass spectrometer coupled will gas chromatograph of model 5890 series II (Hewlett Packard, U.S.A.) with capillary column of $30 \mathrm{~m}$ long, flame ionization detector and helium as carrier gas was used in this investigation.

\section{Preparation of bis-2-chloroethyl sulphide :}

A sample of bis-(2-chloroethyl) sulphide was prepared in the laboratory according to the procedures mentioned in the literatures[4].

\section{GC/MS analysis}

The sample of reaction mixture was injected to GC/MS with the following operating coriditions length of capillary column. $30 \mathrm{~m}$ packing material : diphenyl methyl siloxane carrier gas : Helium with flow rate. $1 \mathrm{ml} / \mathrm{min}$.

Temperature ranges $70-300^{\circ} \mathrm{C}$ with rate of $20^{\circ} \mathrm{C} / \mathrm{min}$.

Type of detector: mass selectivity detector.

\section{RE.SULTS AND DISSCUSSIONS}

Bis-(2 chloroethyl) sulfide is a colorless liquid, which in crude state is brown and has a characteristic odor (garlic like). The outstanding physiological property of bis-(2chloroethyl) sulphide is its vesicant action. It acts first as a cell irritant and finally as a cell poison on all tissue surfaces contacted. The first symptoms of bis-(2chloroethyl) sulphide poisoning usually appears in 4-6 hours depending on the corcentration, but in sometimes the latent period may extend to 24 hours, the higher the concentration, the shorter the interval of time from the exposure to the first symptoms. The physiological action of bis-(2-chloroethyl) sulphide may be classified as local and systemic. The local action results in inflammation of the eyes, erythema (redness of the skin) which may be followed by blistering and inflammation of the 
nose, throat, trachea, bronchi, and lung tissue. Systemic effects of bis-(2chloroethyl) sulphide may include malaise, vomiting, and fever. With amounts approaching the lathel dose, injury to bone marrow, lymph nodes, and spleen may result. Such damage is reflected in the peripheral blood by a drop in the white blood cells, and this will cause the bis-(2-chloroethyl) sulphide casualties to be far more susceptible to local and over whelming infections than the normal individual. The median lethal dosage of bis-(2-chloroethyl) sulphide (LCT ${ }_{50}$ ) was $1500 \mathrm{mg} \cdot \mathrm{min} . / \mathrm{m}^{3}$ for inhalation and $10 \mathrm{~g} \cdot \mathrm{min} . / \mathrm{m}^{3}$ for skin absorption (masked personnel). The median incapacitating dosage $\left(\mathrm{LCT}_{50}\right)$ was $200 \mathrm{mg} \cdot \mathrm{min} . / \mathrm{m}^{3}$ for eye injury and 2000 $\mathrm{mg} \cdot \mathrm{min} . / \mathrm{m}^{3}$ for skin absorption (masked personnel).

\section{Analysis of Bis (2-chloroethyl) sulphide by GC/MS}

The gas chromatograph of the prepared sample of bis-(2-chloroethyl) sulphide shows a main peak which is located at retention time of 6.45 minutes On the other hand the mass spectrum is shown in figure (2). The electron impact gives a molecular ion peak (mother peak) located at $\mathrm{m} / \mathrm{z}=158$ with relative abundance of $23.3 \%$. This spectrum is identified by the GC/MS library search as bis-(2-chloroethyl) sulphide. Bis-(2-chloroethyl) sulphide can behave, in the mass spectrometric electronic impact, either as sulphide or halogen compounds. As sulfide, bis-(2-chloroethyl) sulphide has an intense enough parent peak at $\mathrm{m} / \mathrm{z}=158$ and the easily observed $p+2$ peak due to the heavy isotope ${ }^{34} \mathrm{~S}$. in the same time, since it contains two chlorine atoms, it shows distinct peaks of $p+2$ and $p+4$ located at $\mathrm{m} / \mathrm{z}=160$ and $\mathrm{m} / \mathrm{z}=162$ respectively. The mass spectrum of bis-(2-chloroethyl) sulphide can be explained via a fragmentation pattern that occurs through several routes. The cleavage of the $\mathrm{C}-\mathrm{C}$ bond next to $\mathrm{S}$ with the loss of $\mathrm{ClCH}_{2}$ radical from the parent molecular ion leads to the formation of the base peak located at $\mathrm{m} / \mathrm{z}=109 / 111$ either in a linear or fivemembered cyclic structure as follows :

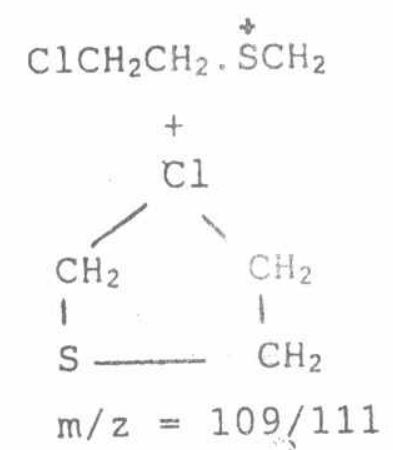

The cleavage of the $\mathrm{C}-\mathrm{Cl}$ bond from the parent ion, can also occur with the formation of either a linear or six-membered ring structure ions located at $\mathrm{m} / \mathrm{z}=123 / 125$ as indicated by the following fragmentation equation :

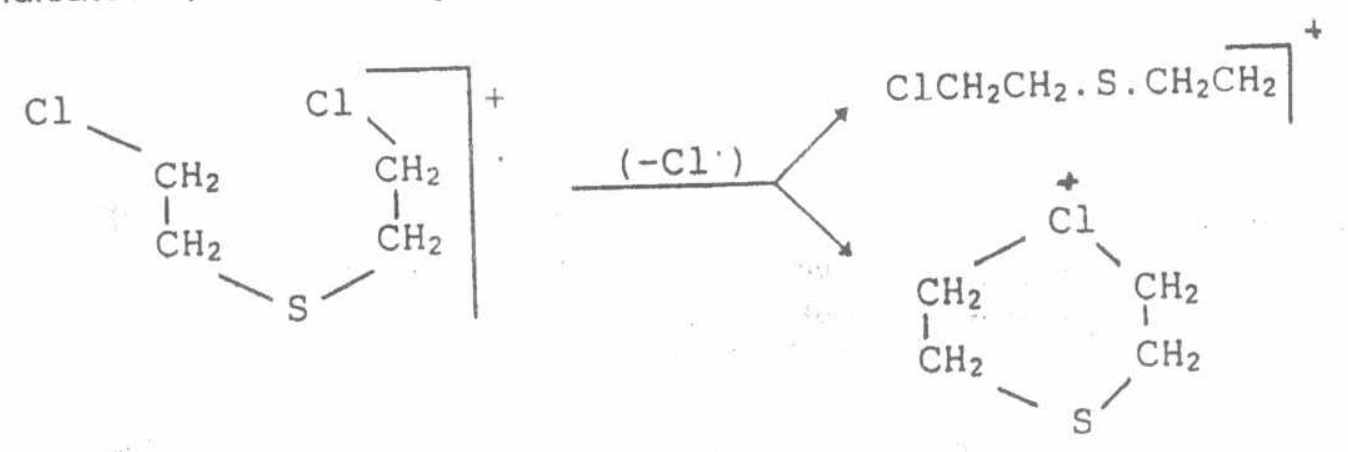


The fragment ion located at $\mathrm{m} / \mathrm{z}=96 / 98$ can be explained by the probable loss of vinyl chloride from the parent ion by the $\mathrm{H}$ transfer and elimination of the olefin, as follows :

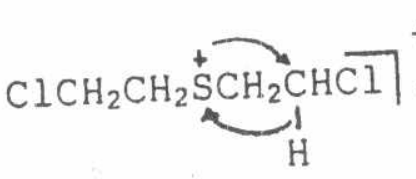

$$
\begin{aligned}
& \mathrm{ClCH}_{2} \mathrm{CH}_{2} \mathrm{SH} \\
& \mathrm{m} / \mathrm{z}=96 / 98
\end{aligned}
$$

From this formed fragment ion it's $p-1$ peak at $\mathrm{m} / \mathrm{z}=95 / 97$ can be produced via the loss of $\mathrm{H}$. The peak observed at $\mathrm{m} / \mathrm{z}=60$ and 61 can be explained by the further loss of $\mathrm{Cl}$ or $\mathrm{HCl}$ as indicated below :

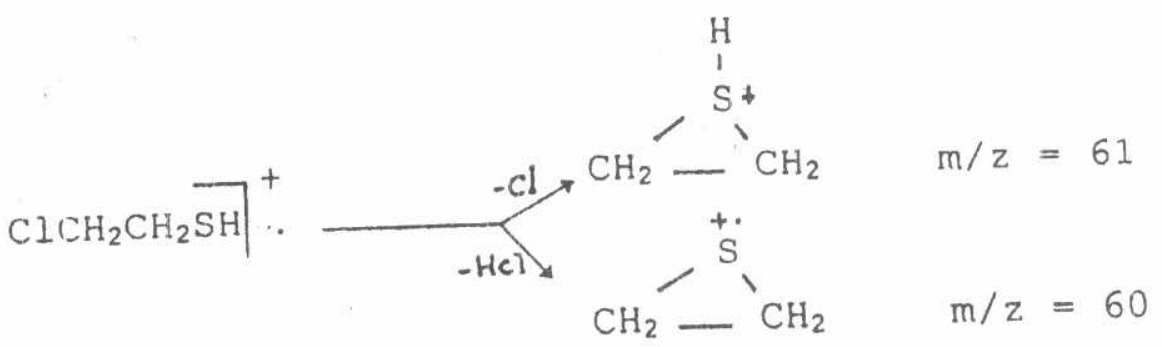

The peak at $\mathrm{m} / \mathrm{z}=81$ and its $\mathrm{p}+2$ at $\mathrm{m} / \mathrm{z}=83$ having very small abundance can be attributed to the loss of $\mathrm{CH}_{3}$ radical from the ions $\mathrm{m} / \mathrm{z}=96 / 98$ as follows :

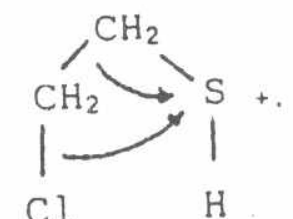

$\mathrm{m} / \mathrm{z}=96 / 98$
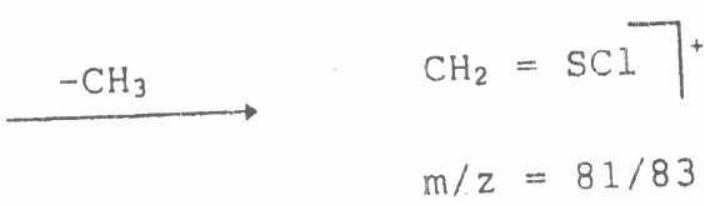

from the base peak as follows :

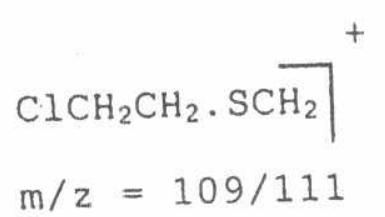

$\mathrm{m} / \mathrm{z}=109 / 111$

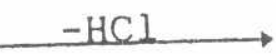

$\mathrm{CH}_{2}=\mathrm{CH} \cdot \mathrm{SCH}_{2}$

$\mathrm{m} / \mathrm{z}=73$

The strong peak at $\mathrm{m} / \mathrm{z}=63$ and its $\mathrm{p}+2$ at $\mathrm{m} / \mathrm{z}=65$ may be due to the cleavage of $\mathrm{S}$ $\mathrm{C}$ bond of the molecular ion with the positive charge being maintained on the halogen containing fragment as illustrated: 
These main routs of fragmentation of bis-(2-chloroethyl) sulpniae III แI IIlaso spectrometer by the electronic impact can be used in the analysis of toxic samples to prove the presence or absence of bis-(2-chloroethyl) sulphide. The alcoholic extract prove the presence or absence of
of various contaminated samples can be injected in the mass spectrometer coupled
with gas chromatograph for analysis. The mechanistic explanation of the formation of the last mentioned ions can be summarized in the following scheme :

S-Mustard $+e^{-} \stackrel{-2 e^{-}}{\longrightarrow}$<smiles>[CH]C</smiles><smiles>CC</smiles><smiles>C1CCSC1</smiles><smiles>C[C+]CCS</smiles>

$$
\mathrm{m} / \mathrm{z}=158 / 160 / 162
$$
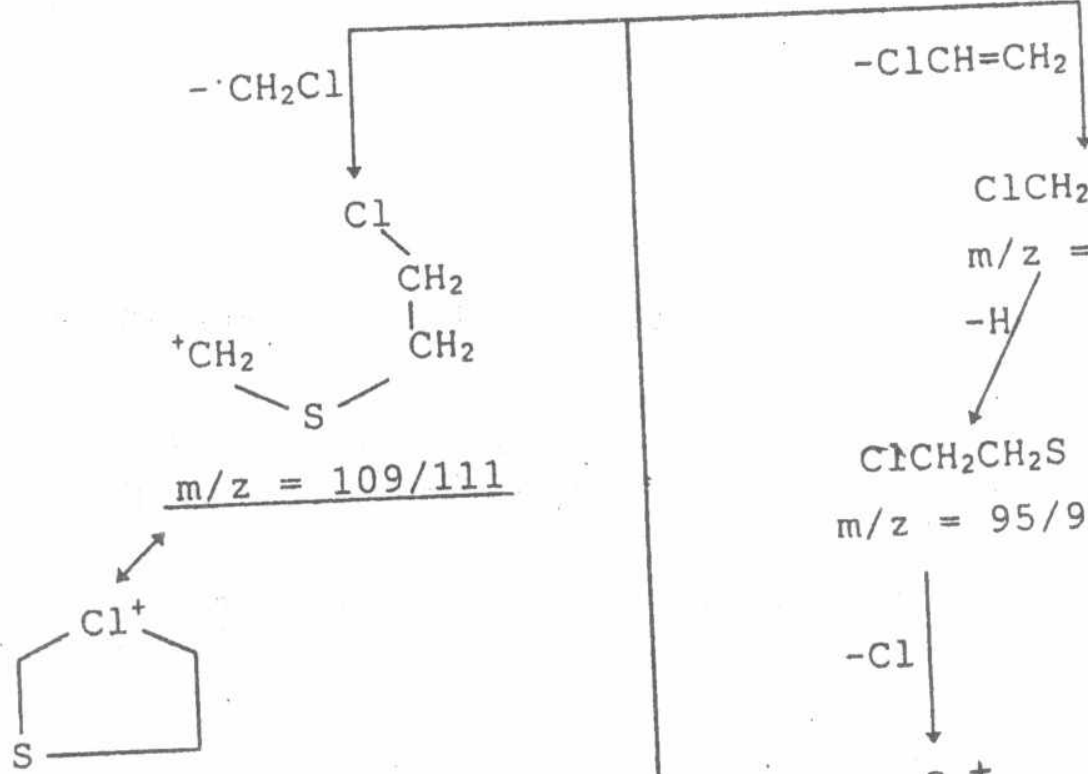$$
\mathrm{ClCH}_{2} \mathrm{CH}_{2} \mathrm{~S}
$$

$\mathrm{m} / \mathrm{z}=95 / 97$
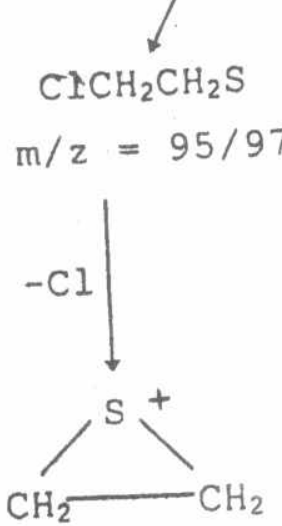

$\mathrm{m} / \mathrm{z}=60$

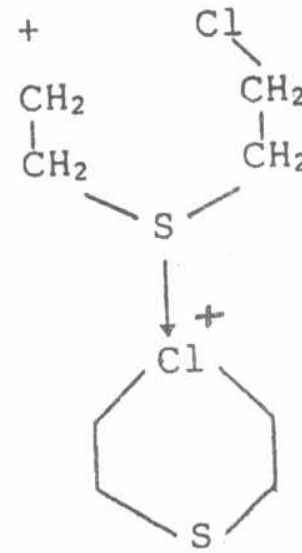


The second peak shown on the gas chromatograph spectrum is located at time 8.45 minutes. Its mass spectrum is shown figure (3). The electron impact gave a molecular ion peak located at $\mathrm{m} / \mathrm{z}=190$ which is proposed to be to bis(2-chloroethyl sulphone $\left[\left(\mathrm{ClCH}_{2} \mathrm{CH}_{2}\right)_{2} \mathrm{SO}_{2}\right]$. Its base peak is located at $\mathrm{m} / \mathrm{z}=63$ with relative abundance $100 \%$. Other abundant ions are formed at $\mathrm{m} / \mathrm{z}$ values of $162,155,128$ $1019,92,97,51$, and others. The third peak shown on the gas chromatograph spectrum is located at time 11.057 minutes. Its mass spectrum is shown in figure (4). The electron impact gave a molecular ion peak located at $\mathrm{m} / \mathrm{z}=262$ which is explained as bis (2-chloroethyl thioethyl) ether $\left[\left(\mathrm{ClCH}_{2} \mathrm{CH}_{2} \mathrm{SCH}_{2} \mathrm{CH}_{2}\right)_{2} \mathrm{O}\right]$ having the name oxo-mustard. The base peak is located at $\mathrm{m} / \mathrm{z}=123$ with relative abunclance $100 \%$. Other abundant ions are formed at $\mathrm{m} / \mathrm{z}$ values of $218,182,109,94,63,59$ arid others. The area normalization technique is used to evaluate the purity of the bis-(2-chloroethyl) sulphide used in this application and it was found to be $97.093 \%$ as shown in table ( ).

\section{CONCLUSION}

The utilization of mobile mass spectrometer for both monitoring and control of air pollutants in the field is very important.

It can be considered as the highly sensitive analyzer especially suitable for the detection of potentially hazardous chemical compounds as Bis-2-chloroethyl sulphide.

The most specific and unique ion fragments produced by its electronic impact in the mass spectrometer are located at $\mathrm{m} / \mathrm{z}$ values of $109 / 111,96 / 98,81 / 83,123 / 125$, and 60 .

The molecular ion peak is located at $\mathrm{m} / \mathrm{z}=158$ with relative abundance of $23.3 \%$

These unique ions can be used to program the mass spectrometer for the analysis of the contaminant in interest. This detection can be updated at any time by providing the suitable ions data for other new pollutants.

\section{REFERENCES}

1- Milner, B. "Chemical Detection Systems Now and Tomorow" Military Technology, No. 3 (1989).

2- Daskal, S.E. "Developments in U.S. Chemical Warfare Defense", National Defence, vol. 70, No. 410, (1985).

3- Jane's NBC Protection Equipment" 1988-1989.

4- Department of the army and the air force"Military Chemistry and chemical compounds" field Manual, USA, Page 3-8 (1975). 


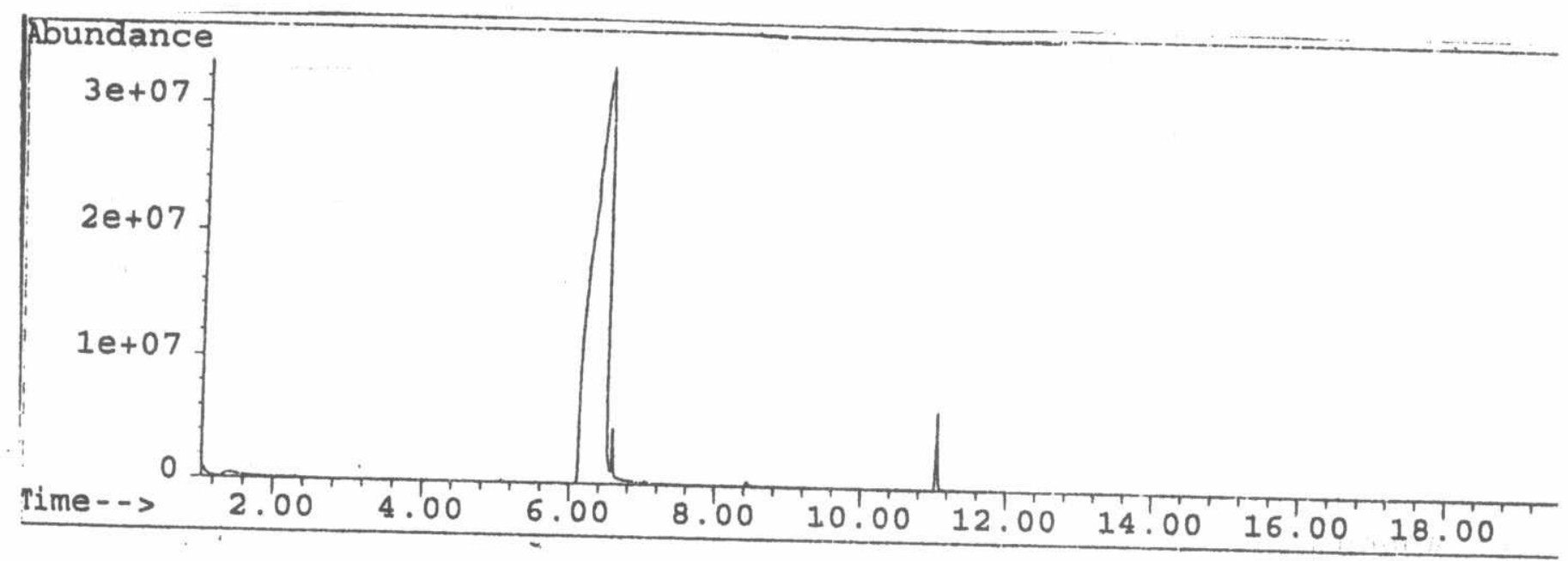

Figure( : Gas chromatograph of the prepared s-mustard .

\begin{tabular}{|rrrr|}
\hline $\begin{array}{r}\text { Retention Time } \\
\text { (min.) }\end{array}$ & $\begin{array}{r}\text { Area } \\
\text { (counts) }\end{array}$ & Area $\%$ & Ratio $\%$ \\
\hline Total Ion Chromatogram & -34790291 & -0.627 & -0.645 \\
1.420 & 5391377012 & 97.093 & 100.000 \\
6.464 & 11320805 & 0.204 & 0.210 \\
8.447 & 115292991 & 2.076 & 2.138 \\
11.057 & & & \\
\hline
\end{tabular}

Table (/) : Area report of prepared s-mustard .

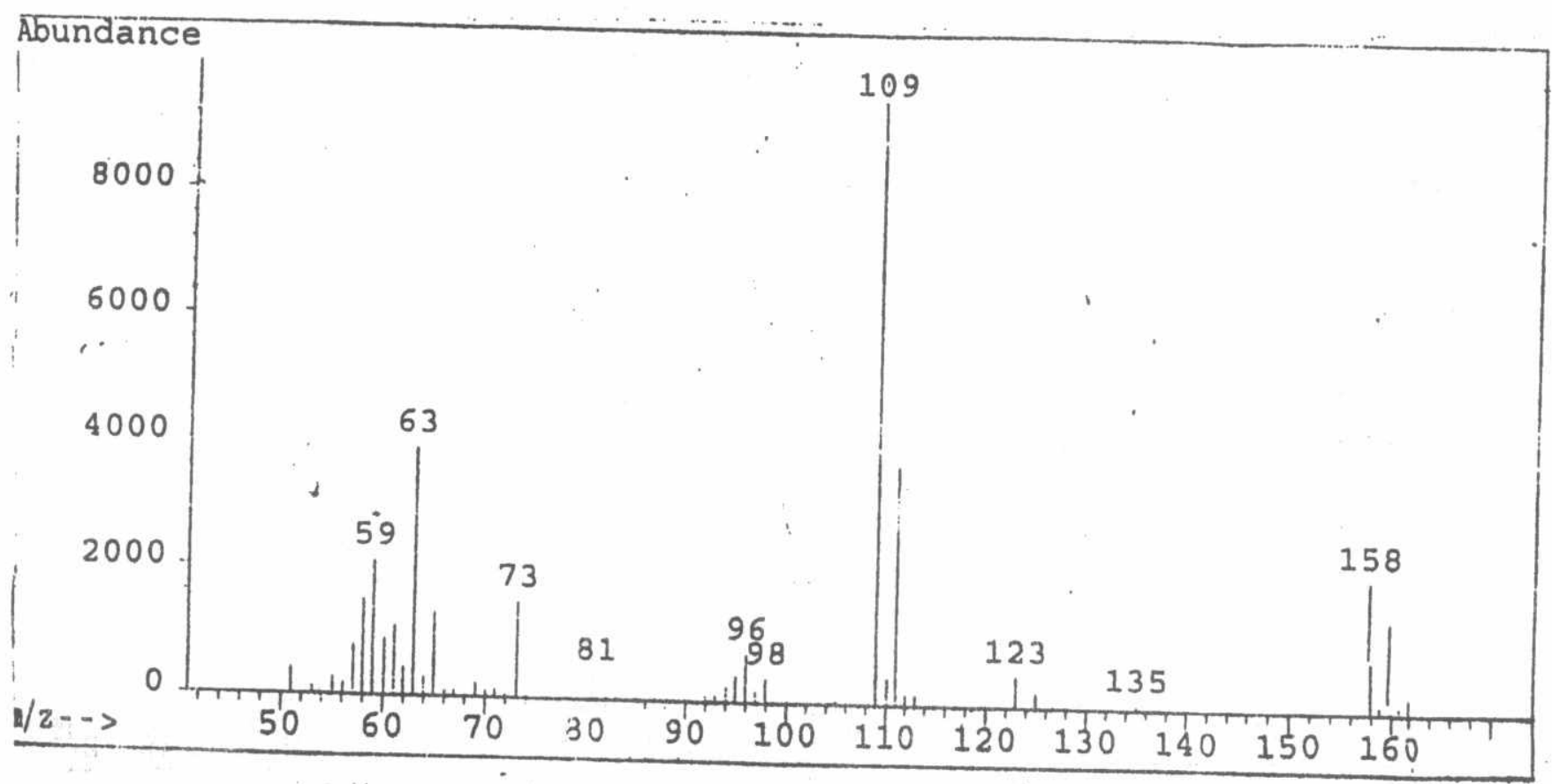

Figure (2): Mass spectrum of the prepared s-mustard. 


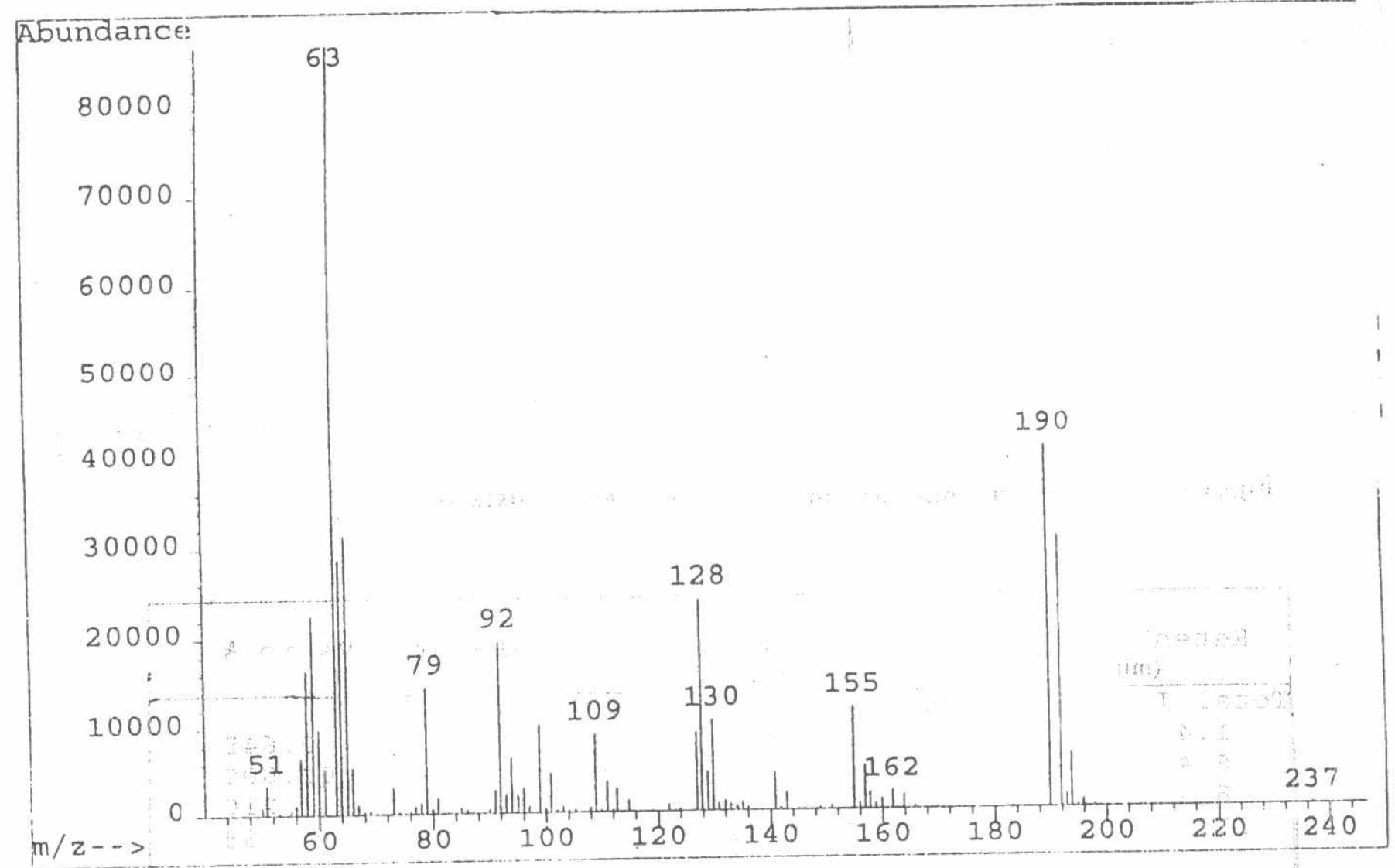

Figure ( 3) : Mass spectrum of bis (2-chloroethyl) sulfone .

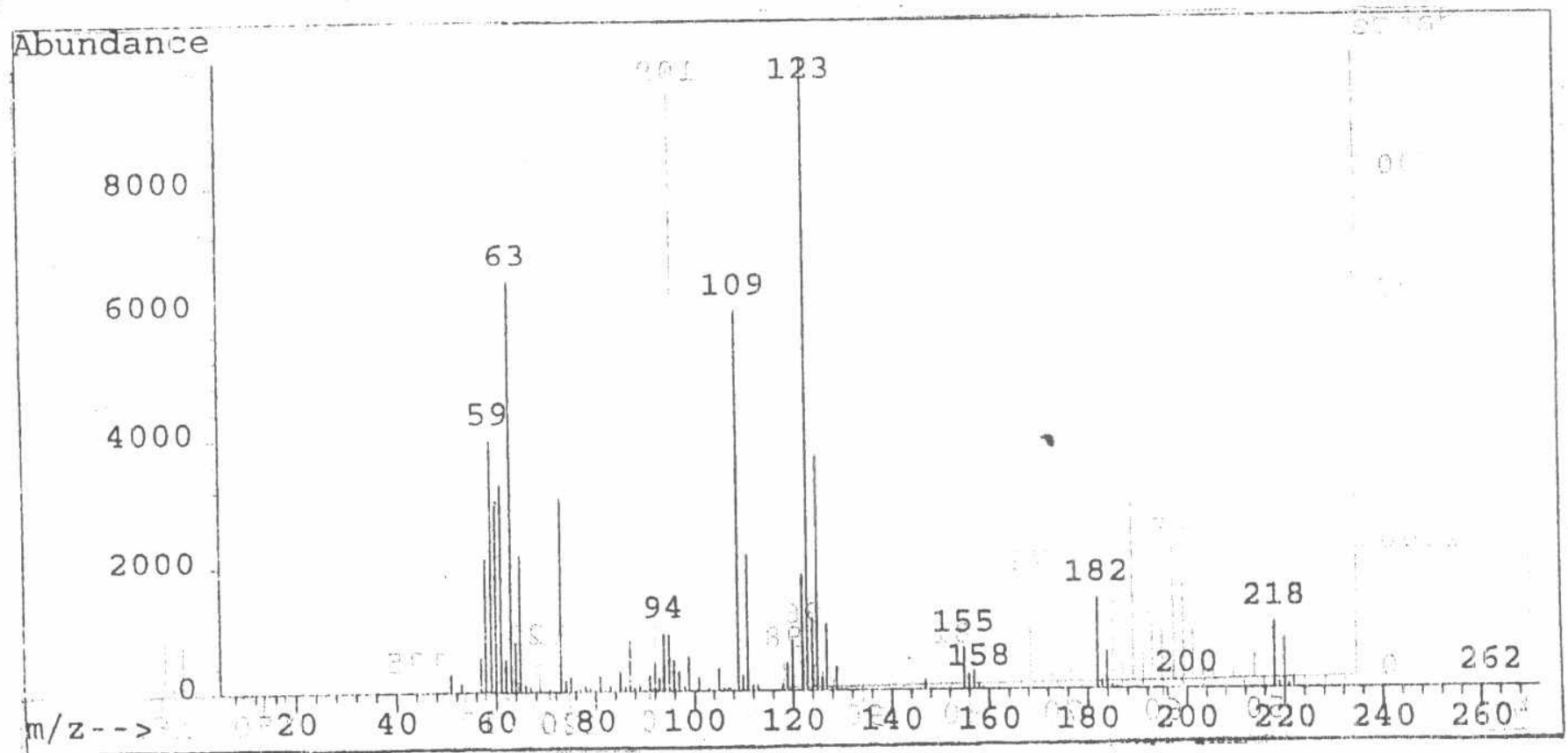

Figure (4): Mass spectrum of bis (2-chloroethyl thioethyl) ether 